\title{
MIXED MELON PRODUCTION IN CALIFORNIA
}

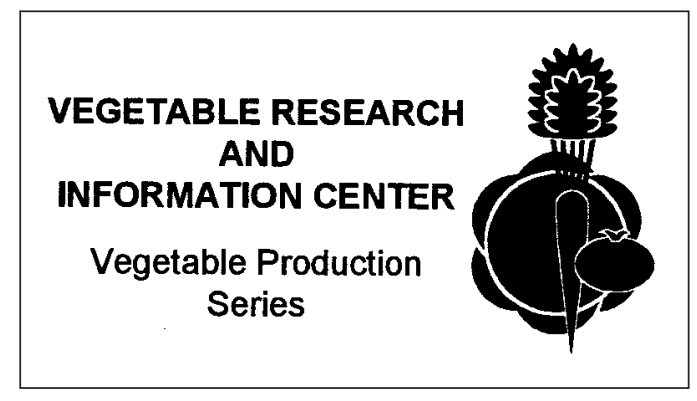

\section{PRODUCTION AREAS}

Mixed melons (Cucumis melo L. Inodorus group) include honeydew, crenshaw, casaba, Juan Canary, Santa Claus, and Persian. Most of the mixed melon acreage is sown to honeydew, with crenshaw being the next most popular type. Although yields vary with season, disease incidence, and type of melon, fields can yield 1,200 to 1,300 cartons per acre. Yields are usually considerably less.

Mixed melons are produced in the northern Central Valley (Sacramento and Stanislaus Counties); the Central Valley (Kern, Fresno, Kings, Merced, and Tulare Counties); and the southern deserts (Imperial and Riverside Counties).

\section{HONEYDEW ACREAGE AND VALUE}

\begin{tabular}{lccc}
\hline Year & Acres & $\begin{array}{c}\text { Average yield } \\
\text { (tons/acre) }\end{array}$ & $\begin{array}{c}\text { Gross } \\
\text { value/acre }\end{array}$ \\
\hline 1994 & 18,100 & 7.8 & $\$ 2,496$ \\
1993 & 16,500 & 8.0 & $\$ 2,672$ \\
1992 & 17,500 & 9.0 & $\$ 2,340$ \\
\hline
\end{tabular}

Source: California Agricultural Statistics 1994 (Sacramento: California Department of Food and Agriculture, 1995).

\section{VARIETIES AND PLANTING}

The standard open-pollinated honeydew is Green Flesh Honeydew. The hybrids Silver World (71-151), Morning Ice, Honey World, and Honeybrew are also grown. Orange-flesh honeydews or orange-flesh melons such as Honey Gold are grown on a limited scale. White Crenshaw is becoming more popular than Green Skinned Crenshaw due to sunburn resistance. White Crenshaw has a pale yellow skin and salmon-colored flesh. Statewide, seeding rates vary from 0.5 to 1.0 pound per acre $(0.56-1.1 \mathrm{~kg} / \mathrm{ha})$ for hybrids and 1 to 2 pounds per acre (1.1-2.2

\author{
Keith S. Mayberry, University of California Cooperative \\ Extension Farm Advisor, Imperial County \\ Timothy K. Hartz, University of California Cooperative \\ Extension Specialist,Department of Vegetable Crops, \\ University of California, Davis \\ Jesús Valencia, University of California Cooperative \\ Extension Farm Advisor, Stanislaus County
}

$\mathrm{kg} / \mathrm{ha}$ ) for open-pollinated varieties. Desired final in-row spacing is 8 to 10 inches $(20-25 \mathrm{~cm})$.

Southern California. In the desert growing areas of Southern California, mixed melons are planted in January for a late-May to July harvest. Growers use several techniques to promote an early harvest. For spring plantings, slant-bed culture increases soil temperature by orienting the south face of the bed toward the winter sun. To maximize heating, the sun's rays should strike the soil surface at a nearly perpendicular angle. Maximum bed heating is achieved with the bed angle at about 35 to 37 degrees from horizontal.

Seed is planted 0.5 inch $(1.2 \mathrm{~cm})$ deep on 80 -inch (2-m) beds. Custom-built, slant-bed planters using random-flow seeding units are commonly used, and vacuum planters may be used for precision spacing. Seed lines should be located midway up the slope. Growers must locate the seed line correctly as the beds will be reworked and reformed during the season. Forming a bed with a depression at the crown increases the incidence of fruit- and root-rotting fungi.

After the melons are thinned to about 12 inches $(30 \mathrm{~cm})$, growers work the beds to relocate the seed line, shaving soil off the top of the beds and into the furrow. After several passes with small tractormounted discs, the field is virtually flat with seed lines 80 inches $(2 \mathrm{~m})$ apart. Growers then sidedress the field with fertilizer and make new furrows for irrigation.

Another way to plant spring melons is the "midbed trench" method. Growers use a bed shaper to dig a trench or groove in the center of an 80-inchwide $(2-\mathrm{m})$ bed. Although the shape of the trench varies, they are usually 6 to 10 inches $(15-25 \mathrm{~cm})$ wide at the bottom, 20 inches $(50 \mathrm{~cm})$ wide at the top, and 12 inches $(30 \mathrm{~cm})$ deep. Trenches are seeded 
at the bottom using either a random-flow planter or an air-type vacuum precision planter. Pre-emergence herbicide is sprayed in the trench. A tractormounted, plastic-mulch-laying machine is used to stretch a 40 -inch-wide $(1-\mathrm{m})$ sheet of 1 to $1.5 \mathrm{~mm}$ plastic sheet over the trench and secure the edges with soil. The plastic mulch should be laid on a sloping beds to prevent rain from collecting, causing the film to sag and injure the plants.

Fields with midbed trenches are furrow-irrigated to wet the seed lines. No additional irrigation is needed for the next 40 to 50 days. After temperatures begin to rise and the plants touch the plastic, ventilation is needed to prevent injury. Holes are punched by hand or machine to allow water vapor to escape, and the plants acclimate to the lower relative humidity. After a few days, the plastic is removed and the plants are thinned.

Growers of fall melons in the southern desert place the seed in a single seed line down the middle of alternate, 42 -inch $(105-\mathrm{cm})$, north-south beds. The seed is planted about 0.5 inch $(1.2 \mathrm{~cm})$ deep. After emergence, plants are thinned to 6 to 12 inches $(15-30 \mathrm{~cm})$ depending on planting date and melon type.

San Joaquin Valley. Mixed melon culture in San Joaquin Valley differs substantially from that in the Southern California deserts. Fields are generally preirrigated, either by sprinkler or furrow. When the soil is dry enough to till, fields are worked into 40or 80-inch (1-2-m) raised beds. Seed are planted just below the tilled zone, with 3 to 6 inches $(7.5-15 \mathrm{~cm})$ of loose soil over the seeded row to hold in moisture. A single seed line is planted per bed. After seed germinate, the soil cap is removed. With 40 -inch beds, every second bed is seeded; after thinning, the unused bed is split and tilled to make the bed 80 inches with the plant row in the center.

\section{SOILS}

Melons prefer well-drained soils. Sandy or silt loams are sometimes selected for the earliest crop. Heavier soils are preferred because of their greater waterholding capacity, which slows the onset of vine collapse. Beds should be left cloddy to allow maturing melons to develop with minimal soil contact and good aeration.

\section{IRRIGATION}

Mixed melons are usually furrow-irrigated because sprinkling tends to cool the soil. Growers schedule irrigations as needed to allow moisture to be replaced in the beds. Excessive saturation can stimu- late root rot diseases and ground spotting of fruit, especially near harvest. The last irrigation is usually scheduled 1 week prior to harvest.

\section{FERTILIZATION}

Most growers apply preplant $\mathrm{P}_{2} \mathrm{O}_{5}$ at 100 to 150 pounds per acre $(112-168 \mathrm{~kg} / \mathrm{ha})$. Commonly used materials are liquid ammonium polyphosphate (1034-0) as a band application near the seed lines or ammonium phosphate (11-52-0) broadcast before listing the beds. A sidedressing of $\mathrm{N}$ is applied at 150 pounds per acre $(168 \mathrm{~kg} / \mathrm{ha})$. Normally a liquid solution of UAN-32 (urea-ammonium nitrate, 32-00 ) or AN-20 (liquid ammonium nitrate, 20-0-0) is used as the $\mathrm{N}$ source instead of dry $\mathrm{N}$ fertilizers.

\section{POLLINATION}

At least one colony of bees per acre is recommended; one and one-half colonies per acre is optimum. The bees should be distributed on at least two sides of a 40-acre (16-ha) field; distribution of bees within fields is even better. Yields increase with heavy bee saturation. Bisexual, or fruit-producing, flowers open for only one day. On the average, a well-pollinated flower will receive at least 15 bee visits during this time. If poorly pollinated, the flower aborts. The highest quality, earliest maturing, and largest fruit are produced near the crown of the plant. Therefore, an adequate supply of bees must be delivered to the field when the first male blossoms develop.

\section{INTEGRATED PEST MANAGEMENT}

Contact the UC IPM World Wide Web site at http://www.ipm.ucdavis.edu or your local county Farm Advisor for current pest management information (UC IPM Pest Management Guidelines, UC Pest Management Group Publication 33).

Weed mangement. Most growers use only mechanical cultivation and hand hoeing for weed control. Available herbicides have limited effectiveness.

Insect identification and control. Fall melons are attacked by a number of insects including crickets, ground beetles, silverleaf whiteflies, cutworms, aphids, mites, loopers, leafhoppers, and leafminers. Spring melons are attacked by melon aphids, cutworms, mites, loopers, leafhoppers, leafminers, and silverleaf whiteflies.

Disease identification and management. Sudden wilt (Pythium spp.) is a serious problem affecting melons after fruit set. The problem is lessened by alternate furrow irrigation, which allows a portion 


\section{Mixed Melon Production in California • 3}

of the root zone to remain dry. Mosaic viruses including zucchini yellow mosaic (ZYMV), watermelon mosaic II (WMV), papaya ringspot (PRSV), and cucumber mosaic (CMV) are vectored by various aphid species during the spring. There is no control for these viral diseases.

Powdery mildews (Sphaerotheca fuliginea or Erysiphe cichoracearum) are foliar diseases favored by warm weather and moisture that can be controlled by dusting with sulfur or specialized chemical treatments. Other diseases of lesser importance include charcoal rot (Macrophomina phaseolina), root rots (Monosporascus cannonballus, Fusarium spp., Pythium spp., and Rhizoctonia solani), and gummy stem blight (Didymella bryoniae).

Fusarium fruit rot (F. roseum) can cause severe crop losses. Control measures must be preventative (i.e., applied before infection) if they are to be effective.

\section{HARVEST AND HANDLING}

Mixed melons are field packed on mobile platforms or picked and hauled to the edge of the field to small, temporary packing sheds. The melons are packed into cardboard cartons with 5, 6, or 8 melons per 30 -pound $(13.6-\mathrm{kg}$ ) carton. All cartons are packed using a partition that serves as a barrier or cushion between melons to prevent bruising and scuffing.

Honeydew, orange flesh, Persian, and casaba melons, mostly spherical in shape, are the easiest to pack: the melons are oriented with the blossom end up. Juan Canary and Santa Claus melons are football shaped and are packed on their sides (not on their points) with the larger fruit sometimes leaning against the carton or divider. Crenshaw melons, the most delicate, are teardrop shaped and are the most difficult to handle: they must be packed blossom end up or the fruit will break down rapidly, and cartons should be cooled with forced air before shipping.

\section{POSTHARVEST HANDLING}

Mixed melons are sensitive to chilling injury. Honeydews, crenshaws, and Persians store best at $45^{\circ} \mathrm{F}\left(7^{\circ} \mathrm{C}\right)$ and casabas at $50^{\circ} \mathrm{F}\left(10^{\circ} \mathrm{C}\right)$. At lower temperatures, surface breakdown and decay will set in, and abnormal softening and poor flavor will result when fruit are brought to room temperature. High humidity (greater than 90 percent) is recommended to prevent water loss.

\section{MARKETING}

Limited numbers of California mixed melons are available starting in May. Production peaks in August and the season ends in November. Melons are shipped to markets throughout the United States and Canada. A significant number of honeydew melons are exported to Pacific Rim countries.

The University of California, in accordance with applicable Federal and State law and University policy, does not discriminate on the basis of race, color, national origin, religion, sex, disability, age, medical condition (cancer-related), ancestry, marital status, citizenship, sexual orientation, or status as a Vietnam-era veteran or special disabled veteran. The University also prohibits sexual harassment. This publication is available in alternative media on request. Inquiries regarding the University's nondiscrimination policies may be directed to the Affirmative Action Director, University of California, Agriculture and Natural Resources, 300 Lakeside Drive, 6th Floor, Oakland, CA 94612-3560; (510) 987-0096. 